\title{
Japanese Perspectives on "Global History" *
}

\author{
HANEDA Masashi \\ University of Tokyo \\ Tokyo, Japan \\ haneda@ioc.u-tokyo.ac.jp
}

\begin{abstract}
The author stresses delicate but important differences of meaning between "global history" in English and its Japanized form "gurobaru hisutori." After explaining the specific path of Japanese historiography on world history from the end of the nineteenth century to the present, he points out important features of contemporary Japanese view on world history and discusses its merits and demerits. Finally, he underlines the potential of various contributions by Japanese historians who have a particular background and joined the discussion on global history in the world through a different path.
\end{abstract}

\section{Keywords}

Japan, global history, new world history, Oriental history, earthmen and women, identity, connectivity, cross-section, historiography

As in other countries, Japanese academics have not been able to ignore the current trend towards "global history." Although they still comprise a small proportion of the total number of Japanese scholars, researchers engaged in this area are growing in num- 
bers. ${ }^{1}$ Have we chosen to work in this field simply because we are affected by this trend currently in fashion in countries such as the US, the UK and Germany? This, of course, is partly the reason. Many historians use the term "gurobaru hisutori," which is the Japanized pronunciation of the original English word "global history." They remain confident that they work in the same research field as other researchers, mainly in English-speaking countries, and that they are using similar approaches and methods, although their works are usually published in Japanese and hence not easily accessible to non-Japanese historians.

I, too, believe that I am working in the same research field as other global history practitioners. But I use the term "new world history (atarashii sekaishi in Japanese)" to refer to my current efforts, influenced by the specific circumstances of Japanese historiography and present global circumstances. While undoubtedly influenced by international academics, I have followed a particular path in Japanese historiography to arrive at global history independently, only to discover many international colleagues who are working in similar fields, although they have followed different paths to arrive at this point.

* This text comprises the keynote address delivered by the author at the AAWH Congress held at the Nanyang Technological University in Singapore on May 29, 2015 with minimal editing and revision. The author delivered similar addresses prior to the congress at the Freie Universität Berlin (December 8, 2014) and Seoul National University (April 27, 2015). The author expresses his gratitude to the participants of these two research meetings who provided numerous questions, comments, and advice.

${ }^{1}$ As far as the author is aware, Gurobaru Hisutori-no Chousen [The Challenge of Gurobaru Hisutori] (Mizushima Tsukasa (ed.), Yamakawa Shuppansha, Ltd., 2008) is the first work in Japan to cover and use the term gurobaru hisutori. Mizushima, who published a book titled Gurobaru Hisutori Nyumon [An Introduction to Gurobaru Hisutori] (Yamakawa Shuppansha, Ltd.), is one of the leaders in this field. In addition, Shigeru Akita has been inviting researchers from overseas and enthusiastically holding seminars related to gurobaru hisutori at Osaka University since the early 2000s (see the following website for greater detail: http://akita4.wix.com/globalhistoryonline). Akita has also authored a book titled Ajiakara Mita Gurobaru Hisutori [An Asian Perspective of Gurobaru Hisutori] (Kyoto: Minervashobo, 2013) and co-edited Gurobaru Hisutori to Teikoku [Gurobaru Hisutori and Empires] along with Momoki Shirou (Osaka: Osaka University Press, 2013). Other full-fledged research projects related to gurobaru hisutori include Gurobaru Hisutori-no Naka-no Kindai Rekishigaku [Modern Historiography within Gurobaru Hisutori] (Tokyo: Rikkyo University, 2014), Chukinsei Kirisutokyo Sekai-no Tagensei-to Gurobaru Hisutori-eno Shikaku [Pluralism in Medieval and Modern Christendom and Viewpoints on Gurobaru Hisutori] (Grants-inAid for Scientific Research (Scientific Research A), Principal Investigator: Jinno Takashi, 2013 to 2017). In addition to the above, seminars and presentations related to gurobaru hisutori are being carried out on a daily basis at various universities and institutes. 
So, in this paper, I start with the history of Japanese historiography so as to allow others to place me on the distinct path that I, a historian living in contemporary Japan, followed. Next, I introduce here some of my future efforts. However, before I begin, I would like to touch briefly on the differences in meaning and methods of global history as understood in English and in Japanese.

\section{GLOBAL HISTORY AND WORLD HISTORY IN THE ENGLISH SPEAKING WORLD}

The difference between global history and world history is hotlycontested among scholars in the English-speaking world. Since I cannot review all of the arguments, I cite the most recent example: Diego Holstein's interesting and insightful book titled Thinking History Globally (Palgrave Macmillan, 2015). In this book, Holstein stresses that the world studied by world historians is different from the world studied by global historians. According to him, while world historians set the world as the frame for interpretation and narrative, the global historian investigates the interconnected aspects of a world created by globalization ${ }^{2}$. If my understanding is correct, world history does not presume any such preconditions regarding the present situation of the world, whereas global history clearly assumes that globalization is present and that, as a result of this globalization, every part of the world is interconnected. As I discuss later, I believe that world history does, in fact, also make such implicit assumptions. However, what is certain is that the framework of world history is more expansive both in size and timescale.

Gurobaru hisutori as understood by Japanese scholars is certainly not equivalent to Holstein's global history. Generally speaking, Japanese historians of gurobaru hisutori criticize convention-

\footnotetext{
${ }^{2}$ Diego Holstein, Thinking History Globally (New York: Palgrave Macmillan, 2015),
} 144-52. 
al approaches and views regarding world history in Japan and propose new ones. According to Mizushima Tsukasa, the features of gurobaru hisutori are as follows: a long time scale, an expansive spatial scale, a goal of relativizing the interpretation of European and modern histories, emphasis on the interconnectedness of countries and regions, and the introduction of new topics and themes including environmental history and big history ${ }^{3}$. Thus, the scope of gurobaru hisutori is broader than the scope of global history as seen by Holstein. On the other hand, to the extent that gurobaru hisutori attempts to review and reexamine the existing framework and interpretation of sekaishi (world history) in Japan, there is no fundamental difference between gurobaru hisutori and atarashii sekaishi, (or new world history) ${ }^{4}$ in terms of methodology. Historians who represent their work as gurobaru hisutori and those who describe their work as atarashii sekaishi are certainly working in the same field.

Now, let us turn to the history of Japanese historiography. We will start in the latter half of the nineteenth century, when a new style of historical studies was introduced in Japan.

\section{HISTORY OF JAPANESE HISTORIOGRAPHY}

\section{Introduction}

In the latter half of the nineteenth century, Japan's Meiji government imported the model of a modern, state-sponsored university from Germany. The University of Tokyo was founded in 1877 , modeled after Berlin University. ${ }^{5}$ In 1887, a chair of history was established at the university. To fill the position, Ludwig Riess (1861-1928), a disciple of Leopold von Ranke, the famous German

\footnotetext{
${ }^{3}$ Mizushima, Gurobaru hisutori-no chousen, 1-4.

${ }^{4}$ I published a book with this title: Haneda Masashi, Atarashii Sekaishi-e, (Tokyo: Iwanami Shoten, 2011).

${ }^{5}$ For more details on the establishment and subsequent history of the University of Tokyo see the 10-volume Tokyo Diagaku Hyakunen-Shi [The 100-year History of the University of Tokyo] 1984-87 (Historical overview: 3 volumes; Departmental histories: 4 volumes; and Documents: 3 volumes). A summary of the historiography-related courses offered can be found in the Faculty of Letters section in departmental histories vol. 1.
} 
historian, was invited from Germany. He introduced the basic methodology of modern historiography known as "how it essentially was" and taught universal history, that is, the history of Europe. This marks the beginning of modern historical studies in Japan.

However, we should also note that Japanese History, called "kokushi," also started to be taught at the university two years later, in 1889. This was natural given that there had been a long tradition of writing "history" in the Japanese language, and the Meiji emperor had already commissioned an official "history" of Japan to be written in 1869, just after the Meiji restoration. At the same time, we can regard this initiative as the first challenge to the modern Western European system of knowledge. In those days, in Europe, Japan was considered to be an Oriental country, and, as such, its past was not examined within the framework of Historical Studies but, rather, within the framework of Oriental Studies. In contrast, in Japan, European history and Japanese history were studied and taught from the same angle. ${ }^{6}$

In 1907, a chair of Oriental History-or tōyōshi in Japanese-was established at the second imperial university in Kyoto. ${ }^{7}$ An equivalent chair was also established at the University of Tokyo in 1910. Since two courses of historical studies already ex-

${ }^{6}$ In a speech delivered in 1889 at the meeting to establish the Historical Society of Japan, Shigeno Yasutsugu explained the methods and goals of historiography as follows: "Based on materials assembled at the Historiographical Institute and using the methods for studying Western history, we will endeavor to investigate the historical accomplishments of our country and to organize and use these for the benefit of our nation.” Regarding the significance of the establishment of the Historiographical Institute at the Tokyo Imperial University, see the discussion by Narita Ryuichi in Rekishigaku-no Positionality [the Positionality of Historiography] (Tokyo: Azekura Shobo, 2006), 95-99.

${ }^{7}$ The concept of "Oriental history" was first used publicly in a guideline for high school teachers issued in1894. For further detail regarding the origins of tōyosshi (Oriental History) and Naka Michiyo, who is credited with creating the concept of $t \overline{o y} \overline{o s h} i$, see Kubodera Koichi's Tōyōgaku Kotohajime: Naka Michiyo-to Sono Jidai [The Origins of Oriental Studies: Naka Michiyo and his era] (Tokyo: Heibonsha, 2009). Regarding the establishment of the tōyosshi course at the Kyoto Imperial University, see Kyodai Tōyoggaku-no Hyakunen [100 Years of Oriental Studies at Kyoto University] eds. Tonami Mamoru and Fujii Jouji (Kyoto University Press, 2002). For further detail regarding the meaning of "the Orient" in Japan, see Yamamuro Shin'ichi’s Shisou Kadai-toshiteno Ajia: Kijiku, Rensa, Touki [Asia as an Ideological Theme: Criteria, Linkages, \& Design] (Iwanami Shoten, 2001). 
isted at the time-that is, History (European history) and Japanese History-it was natural, from an academic point of view, that this new course concerning the countries lying between Japan and Europe, was introduced. There had already been a long tradition of kangaku (Han studies) in Japan. At the time, Oriental History meant the history of China and surrounding regions including Korea, Manchuria and Central Asia (Saiiki). It is significant that Oriental History largely excluded the history of Japan.

The establishment of Oriental History was motivated by politics rather than tradition. Miyazaki Ichisada, a famous historian from Kyoto University, candidly explained the meaning behind the establishment of the chair of Oriental History as follows:

"Frankly speaking, the discipline of tōyōshi-or Oriental Historywas established with mission of realizing a time when Japan could stand up against the Western invasion, with the Orient at its back. ${ }^{8}$

With this, the institutionalization of historical studies in Japan into three departments was complete. These three histories were also taught in high schools and Japanese intellectuals shaped their views of the history of the world by combining elements of the three.

The salient characteristics of each of these histories can be summarized as follows:

1. European interpretations of its own history were imported into Japan with little modifications and integrated into the Japanese view of world history.

2. It was presumed that Japan and other "Oriental countries" had a history of their own separate from Western Europe, which was studied in parallel to European history in the same departments of history.

3. Unlike the histories of France, Germany and other European countries which were studied as 'European' history, Japan's history was regarded as totally independent from the histories of other countries and not included in Oriental

${ }^{8}$ Miyazaki Ichisada Zenshu 2: Tōyōshi [The Complete Works of Miyazaki Ichisada Vol. 2: Oriental History] (Tokyo: Iwanami Shoten, 1992), 345-46. 


\section{History.}

These characteristics provide insights into the world-view of Japanese intellectuals at the time: namely that the world was divided into three parts: the nation state of Japan, European countries, with which Japan had to catch up, and Oriental countries, which Japan had to lead in opposition to the West.

In this way, the world-views and views of the history of the world of Japanese intellectuals resonated, interlinked and influenced each other during this period.

\section{After the Second World War}

The basic division of historical studies at major universities into three departments did not change even after Japan's defeat in WWII. ${ }^{9}$ The contrast between the victorious West and the defeated East may have been obvious to all Japanese intellectuals. However, even if the justification for separating Japan from other countries in the Orient was lost, Japanese intellectuals seemed to want to keep their national history separate.

In contrast to the organization of research, which did not change, the curriculum for high school students changed substantially. It is said that the Ministry of Education established curriculum guidelines for high schools based on suggestions from the general headquarters of the occupation forces. The term "world history" (sekaishi in Japanese) appeared officially for the first time in the second curriculum guideline issued in $1951 .^{10} \mathrm{At}$ this time, people's world views and views of world history corresponded closely, similar to situation before the WWII. The concept of world history had, therefore, existed before WWII, several

${ }^{9}$ For a brief summary of emphasis on kokushi (Japanese History) and the Japanese imperial view of history during WWII, the "philosophy of world history" held by scholars at the Kyoto University known as the "Kyoto school” and Rekishigaku Kenkyu [Historiographical Research], which was critical of this philosophy, see the above-mentioned Rekishigakuno Positionality [the Positionality of Historiography] 104-18.

${ }^{10}$ The Ministry of Education's curriculum guidelines since the end of WWII are available in digital form online at the following website: https://www.nier.go.jp/guideline/ 
books with "world history" as part of their title being published." However, the concept was not well-known and was rarely used, especially by Japanese historians. As such, this introduction into the high school curriculum can be regarded as the birth of "Sekaishi (World History)."

At first, sekaishi represented a combination of the former Oriental and Occidental Histories, since there was no other interpretation then available. For more than fifty years, people had viewed the world in terms of a dichotomy between the West and the East, with Japan serving as the leader of the latter. Especially after WWII, the contrast between a superior, modern West and an inferior, archaic East that lagged behind was widely accepted and this image encountered no strong objections from the Japanese public. As such, most of the early sekaishi texts focused on modern Western History. Only a small space was allotted to Oriental History. The following passage from the first curriculum guideline issued in 1947 aptly illustrates Japanese intellectual perception of the world at the time:

Since modern Western culture is excellent and superior, it is logical that it overwhelmed archaic Eastern culture. Now the world becomes one and the East is devoting itself to learning and digesting this superior culture. ${ }^{13}$

But, with regard to high school education, Japanese history remained independent, even though Japan was considered to be a part of the Orient, and continued to be taught separately from

${ }^{11}$ For example, there is a 10-volume series titled World History published by Kawade Shobo from 1940 to 1942. In addition, an example of the vigorous philosophical debate regarding world history mentioned in footnote 10 can be found in Koyama Iwao's Seikaishi-no Tetsugaku [The Philosophy of World History] (Tokyo: Iwanami Shoten, 1942).

${ }^{12}$ With regard to the origins of "World History" as a discipline of study and research, American scholars often mention the increased attention paid to "World History" in the US during the 1980s as a subject of study in high school (e.g. Kenneth Pomeranz and Daniel A. Segal, "World History: Departure and Variation" in A Companion to World History, ed. Douglas Northrop [Chichester, West Sussex: Wiley-Blackwell, 2012], 15). According to these authors, "World History" as a discipline of study and research did not exist prior to the 1980s. This, however, is clearly incorrect. As mentioned here, "World History" had been taught continuously in Japanese high schools since the 1950s.

${ }^{13}$ Curriculum guideline database, introduction section of the 1947 tôyōshi (Oriental History) (draft) curriculum (https://www.nier.go.jp/guideline/s22ejs3/chap1.htm) 
world history. Thus, a new framework for teaching history comprising Japanese history and world history was introduced in high schools. However, because universities retained the former organization comprising three history departments, there existed no platform for discussing the framework, viewpoint, and interpretation of world history at the research level. This resulted in a sizeable gap between history research and history education.

\section{After 1960}

The curriculum guidelines issued by the Ministry of Education continue to influence the public view of history. First, authors of high school texts have to follow current guidelines, or their books cannot be published. I stress this point, because not all countries exercise such strict control over the content of high school history texts. Second, curriculum guidelines are formed through numerous discussions between prominent historians and high school teachers chosen by the ministry. In this respect, the guidelinesto some extent-reflect the chief interests and main achievements of Japanese historical research. We can observe gradual changes in the perception of world history in Japan by examining the evolution of curriculum guidelines, which are issued every ten years. ${ }^{14}$ Let us review the general trend of world history curriculum guidelines.

We notice that there is a split in the framework of Oriental History into the histories of several civilizations (or regions) after 1960. The Islamic world was the first to be separated and treated independently, because there existed a tradition of research and a concept of the kaikyouken (the Islamic sphere) before WWII. ${ }^{15}$ South Asia and Southeast Asia followed, corresponding to the

${ }^{14}$ The most recent curriculum guidelines were issued in 2009.

${ }^{15}$ On the introduction of the concept of the "Islamic world" to Japan, see Haneda Masashi, Isuramusekai-no Sozo [Creating the Notion of the Islamic World] (Tokyo: University of Tokyo Press, 2005). Its Chinese translation was published in 2012: Isilansshijie gainian de xingcheng, tran. Liu Liqiao \& Zhu Lili, Shanghai gujichupanshe. See also, Haneda Masashi, "La découverte du "monde musulman" dans le Japon des années 1930," Miscellana Asiatica, Institut Monumenta Serica Monograph Series 61 (2010): 325-43. 
spread of independence in Asian and African countries and the resultant changes in the international order. At the same time, the trend illustrates the recovery of self-confidence and the development and maturation of Japanese historical studies during this period of Japan's rapid economic growth.

After 1970, the simplistic binary interpretation of world history-that of a superior West vs. an inferior East-is no longer seen. The uniqueness and independence of each civilization (or region) is acknowledged and highlighted. Europe is considered one such civilization among others, although euro-centric interpretation and narrative, especially after the 16th century, have, in large part, been preserved. The emphasis on regional civilizations became stronger in the 1990s, the situation not changing much since then. As such, we can safely say that the current Japanese view on world history was fixed at the beginning of the 1990s.

\section{General View of World History in Contemporary Japan}

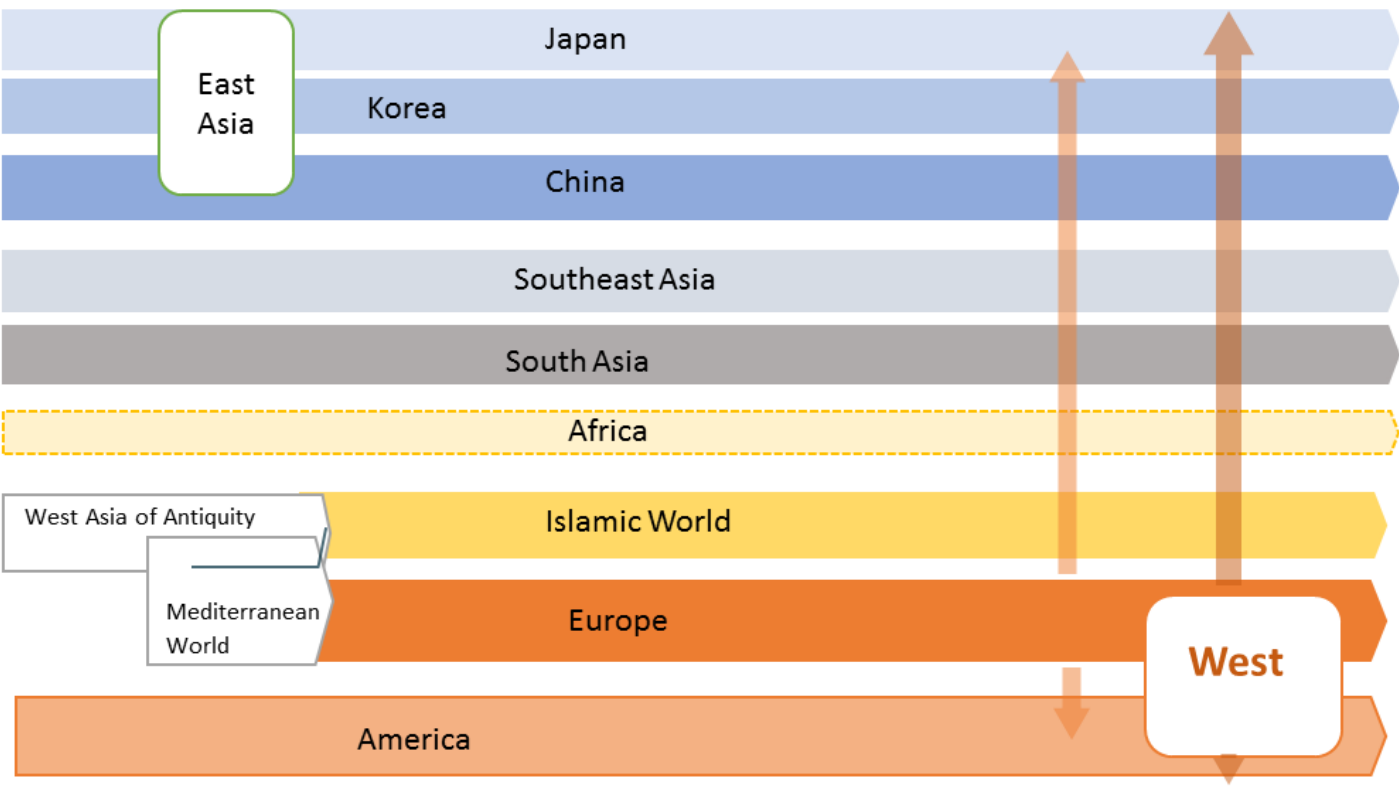


This model-chart ${ }^{16}$ illustrates the general view of world history in contemporary Japan. The world is divided geographically into several civilizations (or regions), and, with the exception of Western Eurasia where the antiquity appears to be complex, each civilization like South Asia or China has its own independent tube- or pipe-like history, that is, a history which has developed from the ancient time to the present in diachronic and chronological way within a tube- or a pipe-like closed framework, without taking any serious contact with the past of other parts of the world. At the same time, it shows European expansion as beginning in the 16th century influenced a lot, exceptionally, other parts of the world and followed by a period of Western domination in the latter half of the 19th century.

I would point out again that the tube-like Japanese History understood in a diachronic and chronological way is considered to be independent of all these other tube-like histories, even if it is widely acknowledged that Japanese past has been influenced a lot, culturally speaking, by China and the West. Although the concept of East Asia is used from time to time, Japan, China and Korea are considered to have had independent and unique histories for a long time. How then can the concept of East Asian History be merged with the histories of these three individual countries? Can East Asian History be understood simply by placing the three independent histories side-by-side? How should they be combined and integrated? In my view, the answer to this question still seems vague and unclear. In any case, I repeat that Japanese history is still taught separately from world history in high schools.

\section{Influence of International Academics}

Since 1950 until today, important international research trends,

${ }^{16}$ It should be kept in mind that this is simply a schematic representation. There are other civilizations and regions that are believed to have histories shaped like a single tube. Although not shown in this figure, the history of central Eurasia is an example of such a history. 
mostly occurring in the West, have influenced Japanese historical studies. Marxism, social history (the Annales school), and the theory of World Systems, among others, have had noticeable impact. Japanese historians, initially learning of such trends through translation, introduced these innovative methods and concepts into historical studies, examining and discussing these in great deal, and subsequently producing a number of high-quality works in Japanese.

Various recent research trends in the English-speaking world, enumerated by Diego Holstein, including connected history, entangled history, comparative history, transnational history, maritime and oceanic history, historical sociology and global history, ${ }^{17}$ have been introduced both individually and generally by Japanese scholars under the term 'gurobaru hisutori.' Wherever necessary, Japanese historians have modified the original meaning and configuration of these trends for these to work within the context of Japanese historiography. By using such modified Japanese codes, researchers have produced works that are mainly in Japanese. In this respect, gurobaru hisutori can certainly move the Japanese view of world history forward. I believe, however, in as far as such endeavors remain Japanese views of historicity, there is no need to call it gurobaru hisutori. As explained above, this term differs in meaning from the English "global history" and, as such, may add unnecessary confusion. The new ways of understanding the history of the world that have been developed simply represent a new world history in the context of Japanese historiography. The concept and term "sekaishi" (meaning "world history") are simple and relatively neutral, at least in Japanese. This is why I prefer to use atarashii sekaishi ("new world history"). ${ }^{18}$

${ }^{17}$ Holstein, Thinking History Globally.

${ }^{18}$ The meanings of the English term "global history" and similar terms in other languages are close but often do not coincide completely. In this paper, I explain the case of the Japanese term "gurobaru hisutori." For discussion of similar problems related to the French term, see Romain Bertrand, "Histoire Globale, Histoire Connectée,” C. Delacroix, F. Dosse, P. Garcia \& N. Offenstadt, eds., Historiographies, I. Concepts et débats (Paris: Édition Gallimard, 2010), 366-77. 


\section{THE MERITS AND DEMERITS OF WORLD HiSTORY IN JAPAN AT} PRESENT

I would like to point out some of the merits and demerits of the current interpretation of world history in Japan. First, the merits. This type of world history covers the past of almost every human community on earth. As such, we could say that it is geographically impartial. As a consequence, most Japanese youngsters who learn world history in high school have a fairly good understanding of the histories of other countries, although their perspective may remain somewhat Japanese.

In the US, the concept of a world history comprising Western civilization with the addition of East Asia emerged for a short period in 1950s. It has been said that the quality of the concept was not high and was generally not accepted. ${ }^{19}$ In comparison, it can be said that Japanese researchers had discussed the creation and description of world relatively earlier and that the results were reflected in high school texts. I repeat that similar to the situation in the earlier period, this view of world history corresponds closely with the world-view held by most Japanese intellectuals and, consequently, that of the Japanese media, politicians and the general public.

Next, let us examine the demerits of Japanese world history. Such an interpretation of world history may enable people to hold onto a naïve belief regarding the independence and uniqueness of Japan's own history. It urges people to retain a strong and almost unconscious hold on the premise that Japan has existed and continues to exist as a separate historiographical category. As consequence, such a premise may cause Japanese people believe that a clear distinction continues to exist between Japan and foreign countries (gaikoku). Some may argue that this is a merit that enables people to form an attachment to the nation state of Japan-in other words, to form a Japanese identity. This may have been a merit at some time in the past, but I believe it is by no

\footnotetext{
${ }^{19}$ Pomeranz and Segal, "World History: Departures and Variations,” 17.
} 
means a merit today. I will discuss this point in greater detail later.

In addition, such an understanding of world history may encourage people to make similar distinctions between regions or civilizations: Europe is different from the Islamic world; Southeast Asia is different from South Asia, etc. I strongly feel that this approach of discriminating between civilizations or regions stems from the conventions of historical interpretation in nineteenth century-Western Europe, at a time its intellectuals were striving to identify European uniqueness and characteristics to differentiate themselves from others. ${ }^{20}$

\section{TOWARDS A NEW WORLD HISTORY}

Efforts should be made to overcome the shortcomings of Japanese world history in its present form. As I have repeatedly stated here, people's world-view or self-identity and their view of world history are closely interlinked and mutually influence each other. We have to have an appropriate view of world history, so as to form a world view or perception of the world that is (1) an accurate reflection of the present situation of the world and (2) one that helps us to better understand what is happening in the world today.

Does the current world history curriculum help Japanese people in this regard? I do not think so. The current view of world history certainly helps the Japanese towards a strong national identity, but it does not help the Japanese to see themselves as citizens of the world or as belonging to the earth as earthmen or women. ${ }^{21}$ The wall between Japan and others is too tall and strong. While we still need to retain our national identity, even in this globalized world, at the same time I believe that people's

${ }^{20}$ For discussion related to the fact that Western European intellectuals created the concept of the Islamic World as a contrast to "Europe" and thereby distinguished themselves from "others," see Haneda Masashi, "Modern Europe and the Creation of the "Islamic World', " International Journal of Asian Studies 4, no.2 (2007): 201-20.

${ }^{21} \mathrm{My}$ view on this point is very similar to that of Professor Zhang Weiwei of China, who proposes a concept of "global.” See Zhang, "The World from China,” in A Companion to World History, 408. 
identity can and should be multi-layered. ${ }^{22}$

As long as we regard world history as an assemblage of independent and self-developed tube- or pipe-like diachronic narratives of nations and regions (civilizations) that are located side by side, Japanese people will never develop plural and overlapping identities. The strong Japanese identity that Japan's current world history helps to form prevents people from forging other identities. We need to make an effort to break down or, at least, to lower the wall that divides Japan from other countries. Of course, Japan's current view of world history is not the only cause of the singular and simplistic identity held by most Japanese people, but critically re-examining Japan's current view of world history will lead us in the direction of forming a composite, global identity.

To form a new identity as earthmen or women, we must identify the points and characteristics that are shared with other groups of people, even while there may be many differences. This is why I argue that when we research the past, we must pay more attention to the similarities, connectivities, and intercourse among different groups of people to find interpretations and explanations in a global context and on a long time-scale. We have to view the whole world, even when we are discussing a specific moment in the past somewhere on earth or in the history of some group of people. The history of Japan is not only for the Japanese people. It is for the people of the whole world. We can say the same about the history of China, the US, etc. As for methodology, I think it useful to take a "cross-section" of the entire world at a specific moment in time and to draw a sketch of the world at that time. While we are accustomed to studying the diachronic narratives of a country or a region's past, in this case, we need persuasive strategies for cross-sectionally interpreting the whole world at a given point in time.

Thus, my efforts to create an atarashii-sekaishi, a new world

${ }^{22}$ My idea that we need a new world history is explained plainly in the abovementioned book: Haneda Masashi, Atarashii Sekaishi-he [Towards a New World History]. A Korean translation by Lee Soo Yeol was published in 2014. 
history, are clearly positioned along a trajectory that extends from the current Japanese view of world history. The methods I propose, however, are very much in line with the methods advocated by Japanese as well as international scholars who insist on the importance of global history. It is, above all else, a question having to do with the framework of Japanese scholarship in the Japanese language. In this respect, it is crucial we convince Japanese historians and the public of the importance of integrating Japan's past with the global and to form multi-layered identities in this globalized world.

That said, Japanese historians, having arrived at the field of global history by following a different path from others, can contribute significantly to the discussion based on substantial research achievements in Japanese. It is a good idea to engage in international collaboration by sharing the achievements of Japanese historiography related to world and global history with our international colleagues, which is what I am currently attempting through co-operation with global historians in Berlin, Paris, and Princeton as part of the Global History Collaborative initiative. ${ }^{23}$

23 For more information on this initiative, see the following website: http://coretocore.ioc.u-tokyo.ac.jp/. In addition to regular exchange of researchers and graduate students, we are presenting a series of research workshops and an annual summer school for graduate students. The first summer school titled "The Question of Scale in Global History” will be held at the University of Tokyo and Hokkaido University in September of 2015. 